\title{
Carbon-Negative Cement Manufacturing from Seawater-Derived Magnesium Feedstocks
}

Palash Badjatya, ${ }^{1}$ Abdullah H. Akca, ${ }^{1}$ Daniela V. Fraga Alvarez, ${ }^{2}$ Baoqi Chang, ${ }^{2}$ Siwei Ma., ${ }^{1}$ Xueqi Pang, ${ }^{2}$ Emily Wang, ${ }^{2}$ Quinten van Hinsberg, ${ }^{2}$ Daniel V. Esposito, ${ }^{* 2,3,4}$ Shiho Kawashima*1,4

Columbia University in the City of New York

\author{
${ }^{1}$ Department of Civil Engineering \\ ${ }^{2}$ Department of Chemical Engineering \\ ${ }^{3}$ Columbia Electrochemical Energy Center \\ ${ }^{4}$ Lenfest Center for Sustainable Energy
}

500 W. $120^{\text {th }}$ St., New York, NY 10027

\section{*Corresponding Authors}

Shiho Kawashima: sk2294@ columbia.edu, phone: 212-854-2701

Daniel Esposito: de2300@ columbia.edu, 212-854-2648 


\begin{abstract}
This study describes and demonstrates a carbon-negative process for manufacturing high-strength cement from widely abundant seawater-derived magnesium $(\mathrm{Mg})$ feedstocks. In contrast to conventional Portland cement, which starts with carbon-containing limestone as the source material, the proposed process uses membrane-free electrolyzers to facilitate conversion of carbonfree magnesium ions $\left(\mathrm{Mg}^{2+}\right)$ in seawater into magnesium hydroxide $\left(\mathrm{Mg}(\mathrm{OH})_{2}\right)$ precursors for production of Mg-based cement. After a low-temperature carbonation curing step converts $\mathrm{Mg}(\mathrm{OH})_{2}$ into magnesium carbonates through reaction with carbon dioxide $\left(\mathrm{CO}_{2}\right)$, the resulting Mg-based binders can exhibit compressive strength comparable to that achieved by Portland cement after curing for only two days. Although the proposed "cement-from-seawater" process requires similar energy use per ton of cement as existing processes, its potential to achieve a carbon-negative footprint makes it highly attractive to decarbonize one of most carbon intensive industries.
\end{abstract}

Key words: cement, carbon-negative, decarbonization, magnesium, seawater, electrolysis. 


\section{Main Text}

\section{Introduction}

Portland cement - the key active ingredient in concrete - is one of the most mass-produced materials in the world. Global cement production was 4.1 billion metric tons in 2019,(1) and is projected to grow by $12 \%$ by 2050.(2) Unfortunately, the production of Portland cement accounts for $\approx 7$ percent of global industrial energy consumption and 7-8 percent of anthropogenic $\mathrm{CO}_{2}$ emissions. $(2,3)$ The main component of Portland cement is calcium oxide $(\mathrm{CaO})$, which is almost exclusively sourced from limestone $\left(\mathrm{CaCO}_{3}\right)$. As shown in Figure 1a, the conventional manufacturing process starts from excavating and crushing limestone, which is sintered with clays in a kiln at temperatures reaching $1450^{\circ} \mathrm{C}$ to produce clinker. This process directly releases $\mathrm{CO}_{2}$ during calcination of $\mathrm{CaCO}_{3}$ into $\mathrm{CaO}$ and indirectly releases $\mathrm{CO}_{2}$ due to the use of fossil fuels to heat the kiln to high temperatures. The clinker is ground up to produce cement, which is ultimately mixed with aggregates and water to produce concrete.

If society is going to transition to a carbon-neutral or carbon-negative future, which is essential if global warming is to be limited to $1.5-2.0^{\circ} \mathrm{C},(4)$ alternative construction materials and processing routes must be developed. Currently, the most common approach to reducing the carbon footprint of concrete is to partially replace Portland cement with industrial wastes such as fly ash and slag, although there are challenges associated with quality control and supply of these waste materials, as well as practical limits based on scale.(5) Geopolymers entirely replace Portland cement with fly ash, slag, and clays, and obtain cementing properties through alkali activation. $(6,7)$ Limestone calcined clay (LCC) cements are also derived from limestone but only calcine the clay and use the limestone directly as partial Portland cement replacement, thereby reducing direct and indirect $\mathrm{CO}_{2}$ emissions. $(8,9)$ Many more alternatives have been proposed and studied. $(10,11)$

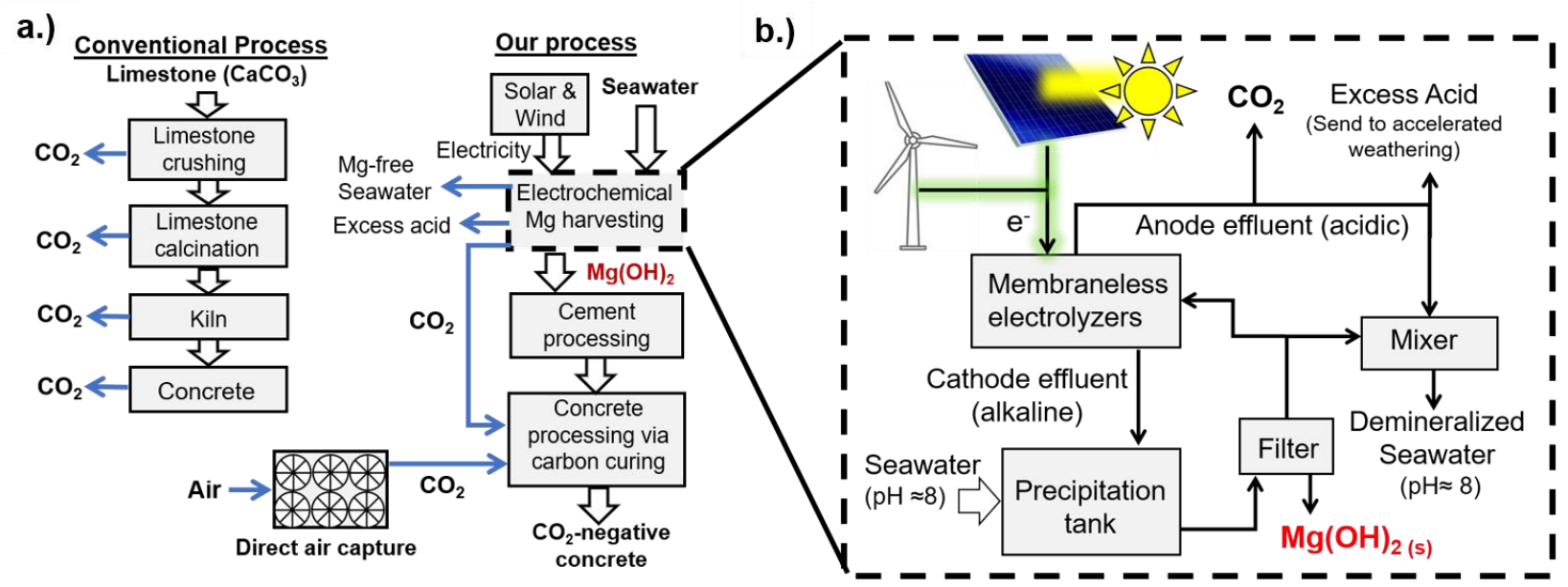

Figure 1. a.) Side-by-side comparison of process flow diagrams for conventional Portland cement and the proposed cement-from-seawater process. b.) Process-flow diagram for the electrochemical approach to harvesting alkali earth metal hydroxides from seawater powered by renewable energy.

More recently, there has been increasing interest in reducing the carbon footprint of Portland cement by incorporating $\mathrm{CO}_{2}$ into the final cement material through carbonation of some 
of the cement phases to produce $\mathrm{CaCO}_{3}$.(12-15) Reactive magnesia (MgO) cement has also been explored as a low-carbon alternate to Portland cements, where solidification occurs via carbonation curing. $(16,17)$ Reports have shown that reactive magnesia that undergoes carbon curing in moderately $\mathrm{CO}_{2}$-rich environments and ambient temperatures produces a hydrated magnesium carbonate-based concrete that can reach compressive strengths of $40 \mathrm{MPa}$ or more, $(18,19)$ which is within the strength range for structural applications. However, reactive magnesia cements are typically derived from carbon-containing magnesite $\left(\mathrm{MgCO}_{3}\right)$, which is geographically limited and also requires calcination that directly releases $\mathrm{CO}_{2} \cdot(20,21)$

The major challenges for improving the energy efficiency and carbon footprint of concrete manufacturing include sourcing carbon-free or low-carbon raw materials that can be (i.) produced at low-cost and large quantities, (ii.) supplied with consistent composition around the world, and (iii.) used to produce concrete with performance comparable to Portland cement-based concrete. Herein, we describe and demonstrate a $\mathrm{CO}_{2}$-free process for the production of magnesium-based cement that has the potential to meet all of these requirements. As illustrated in Figure 1b, this process starts by harvesting magnesium from seawater, where dissolved $\mathrm{Mg}^{2+}$ represents the fourth most abundant ion in the world's oceans.(22) Based on a typical $\mathrm{Mg}^{2+}$ concentration of $52 \mathrm{mM}$, the world's oceans contain enough carbon-free $\mathrm{Mg}$ in the form of dissolved $\mathrm{Mg}^{2+}$ to supply the world's present-day concrete needs for at least 1 million years. In this study, we extract $\mathrm{Mg}^{2+}$ from seawater by using electrochemical reactors called electrolyzers to temporarily elevate the seawater $\mathrm{pH}$ to levels that cause $\mathrm{Mg}^{2+}$ to react with hydroxyls and form insoluble magnesium hydroxide $\left(\mathrm{Mg}(\mathrm{OH})_{2}\right)$ particles that can be easily separated from seawater. In addition to producing the alkaline stream used to form $\mathrm{Mg}(\mathrm{OH})_{2}$, the electrolyzer also produces dilute, salty hydrochloric acid $(\mathrm{HCl})$. A portion of the acidic stream is used to neutralize the demineralized seawater before it is returned to the ocean, but the process also produces excess $\mathrm{HCl}$. If produced at high enough purity, the $\mathrm{HCl}$ may be sold on the open market or used as part of "accelerated weathering" schemes that involve neutralization with alkaline basalt or olivine mineral formations.(23-25) Importantly, the process shown in Figure $1 \mathrm{~b}$ returns $\mathrm{pH}$ neutral water back to the ocean and can be carried out without any $\mathrm{CO}_{2}$ emissions if the electricity used to power electrolysis is generated by renewable solar and wind.

The idea of extracting alkaline earth metals from brine solutions using electrochemical processing has previously been explored by Gilliam et al., who developed electrochemical cells based on anion and cation exchange membranes to generate alkaline salt solutions that were combined with a $\mathrm{CO}_{2}$ source to produce solid carbonate minerals.(26) Ellis et al., also used electrolysis for cement processing when they used 3-compartment membrane-based electrolyzers to aid in the breakdown of limestone as a part of processing for conventional Portland cement.(27) However, this process is still only carbon neutral at best due to the use of limestone as the starting material. In contrast to previous efforts, the proposed process in Figure 1b starts with carbon-free $\mathrm{Mg}^{2+}$ ions and harvests it in the form of solid $\mathrm{Mg}(\mathrm{OH})_{2} . \mathrm{Mg}(\mathrm{OH})_{2}$ is a versatile precursor material that can be converted into a viable construction material by multiple pathways. First, $\mathrm{Mg}(\mathrm{OH})_{2}$ can be converted to reactive $\mathrm{MgO}$ and utilized as cement similar to magnesite-derived $\mathrm{MgO}$.(28, 29) This process requires lower calcination temperatures $\left(500-1000^{\circ} \mathrm{C}\right)(28,30)$ than Portland cement and doesn't involve direct $\mathrm{CO}_{2}$ emissions from the source material. This high temperature calcination step may be avoided by exposing compacted $\mathrm{Mg}(\mathrm{OH})_{2}$ powder to $\mathrm{CO}_{2}$ under elevated 
pressure. De Silva et al., subjected $\mathrm{Mg}(\mathrm{OH})_{2}$ compacts to $20 \mathrm{~atm}$ of $\mathrm{CO}_{2}$ and measured compressive strengths exceeding $60 \mathrm{MPa}$ after 6 hours of carbonation curing.(31) However, that study did not consider the source of the $\mathrm{Mg}(\mathrm{OH})_{2}$.

Herein, we report proof-of-principle experiments based on three key steps that are central to the cement-from-seawater process illustrated in Figure 1: (i.) electrochemical generation of salty $\mathrm{NaOH}$ and $\mathrm{HCl}$ using membraneless electrolyzers, (ii.) precipitation of $\mathrm{Mg}(\mathrm{OH})_{2}$ from seawater, and (iii.) a low-temperature carbonation process for direct conversion of $\mathrm{Mg}(\mathrm{OH})_{2}$ into magnesium carbonate-based binder. After characterizing the properties and performance of the Mg-based binder, the energy use and carbon footprint of the overall process are compared to conventional Portland and $\mathrm{Mg}$ cements. Finally, opportunities and challenges for implementing the proposed process at scale are discussed. Throughout this article, all precursor $\mathrm{Mg}(\mathrm{OH})_{2}$ powders are referred to as "cement", while conventional cement will be referred to as "Portland cement" and the matrix of solids obtained after carbonation will be referred to as "binder". Seawater-derived precipitated $\mathrm{Mg}(\mathrm{OH})_{2}$ was compared against commercial $\mathrm{Mg}(\mathrm{OH})_{2}$, where the latter will be referred to as "standard" brucite.

\section{Results \& Discussion}

\subsection{Electrochemical Production of Acid \& Base with Membraneless Electrolyzers}

Going back to at least 1865 , it has been known that $\mathrm{Mg}^{2+}$ ions can be harvested from seawater by elevating the $\mathrm{pH}$ of seawater such that $\mathrm{Mg}^{2+}$ reacts with hydroxyls $\left(\mathrm{OH}^{-}\right)$to form insoluble $\mathrm{Mg}(\mathrm{OH})_{2 .}(22) \mathrm{Mg}(\mathrm{OH})_{2}$ is still commercially obtained by this means through the addition of alkaline quick lime (Calcium oxide, $\mathrm{CaO}$ ) to seawater.(22) However, the production of $\mathrm{CaO}$, like Portland cement, has a large carbon footprint because it is obtained from limestone. In contrast, our process uses a membraneless electrolyzer (Figure 2a) to generate salty base and acid directly from seawater according to equations (1.) and (2.), respectively:

\section{Oxidation half reaction: $H_{2} \rightarrow 2 H^{+}+2 e^{-} \quad \mathrm{E}^{\mathrm{o}}=+0.059 \cdot\left(\mathrm{pH}_{\mathrm{a}}\right) \mathrm{V}$ vs. NHE (1.)}

Reduction half reaction: $2 \mathrm{H}_{2} \mathrm{O}+2 e^{-} \rightarrow \mathrm{H}_{2}+2 \mathrm{OH}^{-} \quad \mathrm{E}^{\mathrm{o}}=-0.059 \cdot\left(\mathrm{pH}_{\mathrm{c}}\right) \mathrm{V}$ vs. NHE (2.) where $\mathrm{E}^{\mathrm{o}}$ is the standard reduction potential and $\mathrm{pH}_{\mathrm{a}}$ and $\mathrm{pH}_{\mathrm{c}}$ are the $\mathrm{pH}$ at the anode and cathode, respectively. During operation, $\mathrm{H}_{2}$ from the cathode can be directly transferred to the anode where it is oxidized, or it can be collected from the cathode effluent and recycled back to the feed stream (SI Figure S1). In either case, Figure 2a shows how electrolyte is pumped through two porous electrodes to sweep the salty acid and salty base into separate effluent streams, resulting in the following overall reaction:

Overall reaction: $\left.\quad \mathrm{H}_{2} \mathrm{O} \rightarrow \mathrm{H}^{+}\right|_{\text {anode }}+\left.\mathrm{OH}^{-}\right|_{\text {cathode }} \Delta \mathrm{E}^{\mathrm{o}}=0.059 \cdot \Delta \mathrm{pH}$ where $\Delta \mathrm{E}^{\mathrm{o}}$ is the minimum voltage required to drive the overall reaction at the desired $\mathrm{pH}$ difference $\Delta \mathrm{pH}=\mathrm{pH}_{\mathrm{a}}-\mathrm{pH}_{\mathrm{c}}$. Talabi et al., previously demonstrated a similar concept using membraneless electrolyzers for producing acid and base from $\mathrm{pH}$ neutral sodium sulfate and potassium nitrate solutions but did so through water electrolysis that involved the oxygen evolution reaction (OER) at the anode.(32) However, the new reaction scheme given by Equations (1)-(3) is better for generating acid and base in seawater because (i.) the hydrogen oxidation reaction (HOR) is far more favorable than the undesirable chlorine evolution reaction (CER), (ii.) the required cell 
voltage is substantially lower than that required for water electrolysis, and (iii.) it avoids safety concerns about mixing $\mathrm{O}_{2}$ and $\mathrm{H}_{2}$ because $\mathrm{O}_{2}$ is not generated at the anode.

a.)

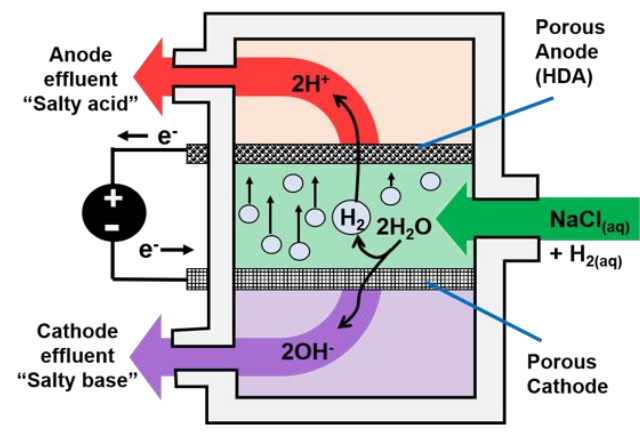

c.)

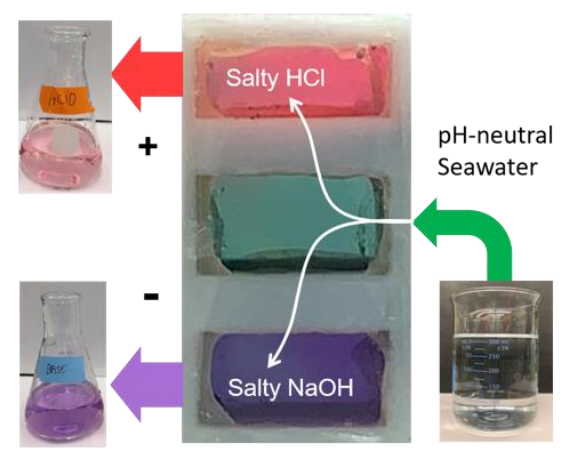

b.)

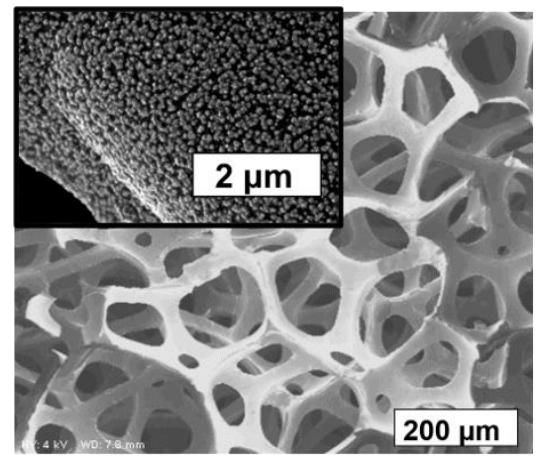

d.)

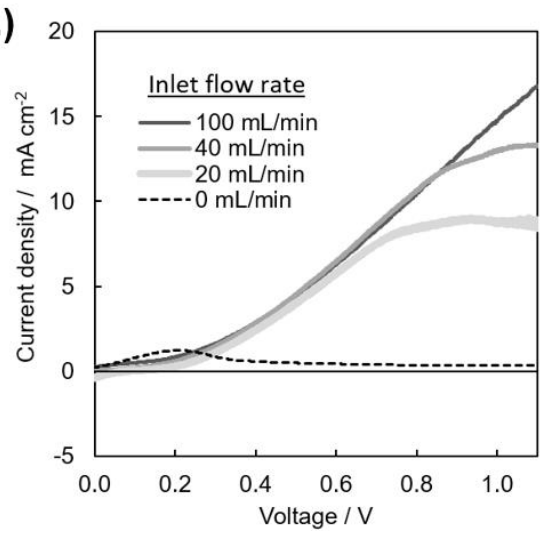

Figure 2. a.) Schematic of membraneless electrolyzer used for splitting seawater into acidic and alkaline streams. b.) Scanning electron microscopy (SEM) images of as-made platinized carbon foam electrodes. c.) Photograph of membraneless electrolyzer during steady-state electrolysis of natural seawater in the presence of a $\mathrm{pH}$ indicator dye, which turns purple or red in alkaline and acidic environments, respectively. d.) Current-voltage ( $i$ - $V$ ) curves recorded for membraneless electrolyzer recorded in $\mathrm{H}_{2}$-saturated $\mathrm{Mg}$-free natural seawater at several different inlet volumetric flow rates. Also shown is an $i-V$ curve taken in the absence of flowing electrolyte or dissolved $\mathrm{H}_{2}$.

The electrolyzer concept in Figure 2a was demonstrated using platinized porous carbon foam electrodes. Figure $2 b$ shows scanning electron microscopy (SEM) images of one such electrode, where the microporous structure of the carbon foam and discrete platinum nanoparticles can be seen in the low- and high-magnification images, respectively. Two identical porous $\mathrm{Pt} / \mathrm{C}$ electrodes were positioned parallel to each other within a 3D-printed membraneless electrolyzer that was outfitted with windows to allow for in situ imaging. A photograph of the device during operation in Mg-free natural seawater is provided in Figure 2c, where $\mathrm{H}_{2}$-saturated natural seawater was fed into the right side of the device at $0.33 \mathrm{~mL} \mathrm{~s}^{-1}$ and salty acid and salty base effluent streams leave the upper left and lower left ports, respectively. For this experiment, universal $\mathrm{pH}$ indicator dye was added to the inlet stream, causing it to change color based on the local $\mathrm{pH}$. The $\mathrm{pH}$ neutral feed stream is pale green, while the alkaline cathode effluent stream turns purple and the acidic anode effluent stream turns red. The absence of purple or red plumes within the electrode gap indicates that there was limited cross-over of the liquid phase products. This observation is further supported by measurement of the $\mathrm{pH}$ of the anode $\left(\mathrm{pH}_{\mathrm{a}}=3.38\right)$ and cathode 
$\left(\mathrm{pH}_{\mathrm{c}}=10.03\right)$ effluent streams, which are similar to those expected for the chosen operating conditions $\left(\mathrm{pH}_{\mathrm{a}}=3.19\right.$ and $\left.\mathrm{pH}_{\mathrm{c}}=10.82\right)$.

The 2-electrode current-voltage $(i-V)$ characteristics of the electrolyzer were also recorded and are provided in Figure $2 \mathrm{~d}$ for different inlet volumetric flow rates. In the absence of any $\mathrm{H}_{2}(\mathrm{aq})$ in the inlet stream, the electrolyzer generates no significant current across the voltage range analyzed. Running the same measurement in $\mathrm{H}_{2}$-saturated $\mathrm{Mg}$-free seawater results in $i$ - $V$ curves with onset voltages of around $0.2 \mathrm{~V}$, followed by linear increases in current density up until the point where mass transfer of dissolved $\mathrm{H}_{2}$ to the anode limits the overall reaction and results in a limiting current plateau at high voltages. This is confirmed by increasing the volumetric flow rate of the $\mathrm{H}_{2}$-saturated inlet stream, which results in a monotonic increase in limiting current with flow rate (SI Figure S2). The relatively shallow slope of the $i$ - $V$ curves can be largely attributed to concentration overpotentials caused by the buildup of a $\mathrm{pH}$ differential between the two electrodes. In contrast, overpotential losses are substantially reduced when the electrolyzer is operated in 0.5 $\mathrm{M} \mathrm{H}_{2} \mathrm{SO}_{4}$ (SI Figure S2) because no significant $\mathrm{pH}$ changes occur.

Although the membraneless electrolyzer generates a relatively dilute salty base stream, its alkalinity is still sufficient to drive $\mathrm{Mg}^{2+}$ precipitation and can be increased further through optimization of the electrode and device designs. It should also be noted that salty $\mathrm{HCl}$ and salty $\mathrm{NaOH}$ can also be generated using electrodialysis stacks based on bipolar membranes (BPMs) comprised of cation exchange membranes (CEMs) and anion exchange membranes (AEMs).(3335) Gilliam et al., have similarly employed electrochemical cells containing separated CEMs and AEMs to generate alkaline and acidic streams from brine solutions based on the reactions given in Equations 1-3.(26) However, the ion exchange membranes in these electrodialysis-type devices present significant technoeconomic challenges with respect to both cost and lifetime.(36) In general, the lack of stable AEMs that can operate in seawater is a major impediment to direct seawater electrolysis technologies.(37) Thus, an electrolyzer that completely avoids the need for membranes has an inherent advantage for operation in seawater. The electrodes of an electrolyzer can also be prone to fouling or degradation, but the recirculating scheme of Figure $1 \mathrm{~b}$ ensures that raw seawater is first sterilized in the alkaline precipitation tank before reaching the membraneless electrolyzer. Removal of $\mathrm{Mg}^{2+}$ ions before the seawater reaches the electrolyzer has the added benefit of avoiding $\mathrm{Mg}(\mathrm{OH})_{2}$ deposits from forming on the cathode, another common concern in seawater electrolysis. $(38,39)$

\subsection{Precipitation and Harvesting of Magnesium Hydroxide from Seawater}

As described above, $\mathrm{Mg}^{2+}$ ions may be converted into solid $\mathrm{Mg}(\mathrm{OH})_{2}$ by reaction with $\mathrm{OH}^{-}$:

$$
\mathrm{Mg}^{2+}+2 \mathrm{OH}^{-} \rightarrow \mathrm{Mg}(\mathrm{OH})_{2(s)} \quad \mathrm{K}_{\mathrm{sp}}{ }^{\mathrm{o}}=5.61 \times 10^{-12} \mathrm{M}^{3}
$$

where $\mathrm{K}_{\mathrm{sp}}{ }^{\circ}$ is the solubility product constant at $25^{\circ} \mathrm{C}$.(40) Consistent with Le Chatelier's principle, increasing $\mathrm{pH}$ shifts equilibrium to the right, causing $\mathrm{Mg}^{2+}$ to be converted into insoluble $\mathrm{Mg}(\mathrm{OH})_{2}$ particles. The $\operatorname{Mg}(\mathrm{OH})_{2}$ (s) initially forms a colloidal suspension that gives the solution a milky color (see Fig. 3a insets), but further growth of particles leads to precipitation as gravity forces larger particles downward. As shown in the SI Figure S3, $\mathrm{Mg}^{2+}$ should begin precipitating from $25^{\circ} \mathrm{C}$ seawater at $\mathrm{pH} \approx 9.1$, and $95 \%$ of $\mathrm{Mg}^{2+}$ should precipitate at $\mathrm{pH} \approx 9.7$.

To determine how much $\mathrm{OH}^{-}$is required to precipitate $\mathrm{Mg}^{2+}$ from seawater with a target yield, varying amounts of $\mathrm{NaOH}$ were added to $350 \mathrm{~mL}$ aliquots of natural seawater. Following 
centrifugation and rinsing steps detailed in the Methods section, the collected $\operatorname{Mg}(\mathrm{OH})_{2}$ (s) was dried overnight and weighed. The composition of several samples was also evaluated using thermogravimetric analysis (TGA), allowing for determination of the mass of harvested $\mathrm{Mg}(\mathrm{OH})_{2}$ by subtracting the weight of residual water and small quantities of $\mathrm{CaCO}_{3}$ from the total weight of the sample. Figure 3a shows how the amount of added $\mathrm{NaOH}$ affected the yield of harvested

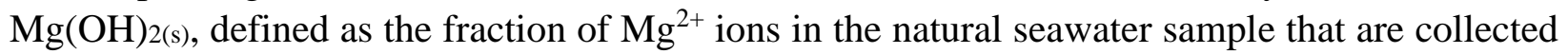
in the form of $\mathrm{Mg}(\mathrm{OH})_{2}$ (s). For this calculation, the concentration of $\mathrm{Mg}^{2+}$ initially present in the sample was determined to be $50 \mathrm{mM}$ based on the amount of $\mathrm{Mg}(\mathrm{OH})_{2}$ collected after titrating the seawater sample with excess $\mathrm{NaOH}$ (4.86 g NaOH per $\mathrm{L}$ of seawater). $50 \mathrm{mM}$ is similar to the "typical" concentration of $\mathrm{Mg}^{2+}$ in the world's oceans, $52.8 \mathrm{mM}$.(41) Figure 3a shows that the yield increases linearly with the amount of $\mathrm{NaOH}$ added to seawater up until $\approx 4 \mathrm{~g} \mathrm{NaOH}$ per $\mathrm{L}$ of seawater, at which point over 2 moles of $\mathrm{NaOH}$ had been added per mole $\mathrm{Mg}^{2+}$ present in the seawater. For constant titrant dosing of $4.86 \mathrm{~g} \mathrm{NaOH}$ per L, yields of $90.7 \pm 4.8 \%$ were obtained for small-scale experiments producing $0.94 \mathrm{~g} \mathrm{Mg}(\mathrm{OH})_{2}$, while yields increased to $99.9 \pm 6.3 \%$ for a larger $62.4 \mathrm{~g}$ batch of $\mathrm{Mg}(\mathrm{OH})_{2}$ due to lower $\mathrm{Mg}(\mathrm{OH})_{2}$ loss during transfer from the centrifuge bottle to the drying rack. For all titrations, Figure 3a shows that the experimentally determined yields are in excellent agreement with the theoretical yield. Samples with varying number of freshwater rinse cycles were also characterized by TGA, showing that a single rinse cycle was sufficient to remove $\mathrm{NaCl}$ below the detection limit (SI Figure S4).

a.)

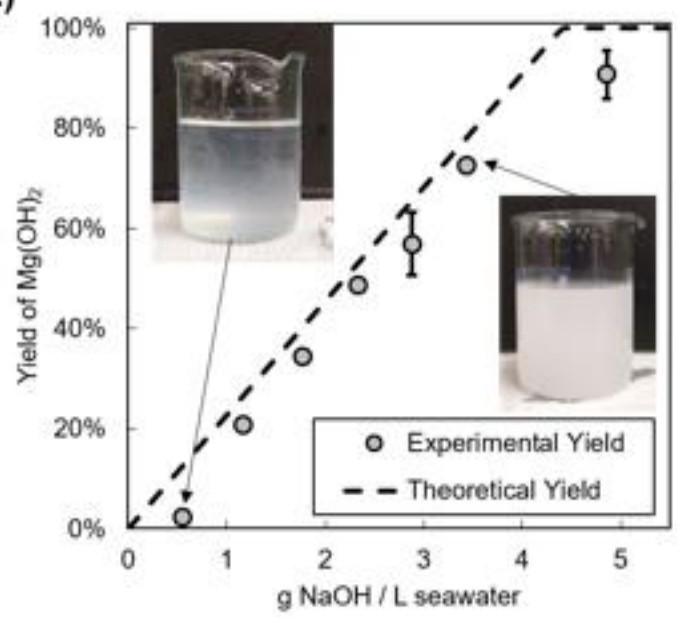

b.)

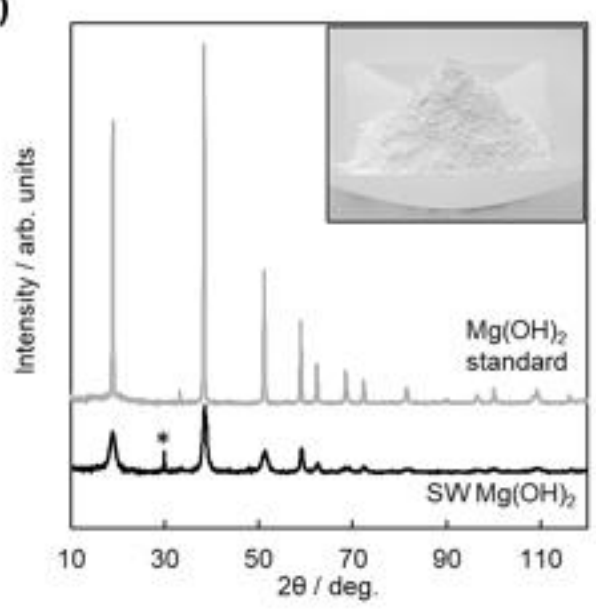

Figure 3. Precipitation of $\mathrm{Mg}^{2+}$ from seawater. a.) Theoretical and experimental yields of $\mathrm{Mg}(\mathrm{OH})_{2}$ obtained from precipitation of natural seawater titrated with $\mathrm{NaOH}$ as a function of the amount of $\mathrm{NaOH}$ titrant. Insets show photos of natural seawater titrated with two different amounts of $\mathrm{NaOH}$. Theoretical yield was calculated based on the solubility constant product for $\mathrm{Mg}(\mathrm{OH})_{2}$ at room temperature (Equation 4) and neglecting any buffering effects from sulfate or carbonate. b.) XRD patterns for standard brucite $\mathrm{Mg}(\mathrm{OH})_{2}$ and seawater-derived $\mathrm{Mg}(\mathrm{OH})_{2}$ were obtained by precipitation using $4.86 \mathrm{~g} \mathrm{NaOH}$ per $\mathrm{L}$ of seawater and rinsing with deionized water. All XRD peaks are associated with $\mathrm{Mg}(\mathrm{OH})_{2}$, except for the peak marked with *, which is attributed to $\mathrm{CaCO}_{3}$. Inset shows a photograph of seawaterderived $\mathrm{Mg}(\mathrm{OH})_{2}$ after pulverization.

After drying in air, the $\mathrm{Mg}(\mathrm{OH})_{2}$ filter cake was first crushed into a fine white powder (Figure $3 \mathrm{~b}$ ) and passed through sieves to give particle sizes between $0.4 \mu \mathrm{m}$ to $75 \mu \mathrm{m}$ that were comparable to the standard brucite powder (SI Figure S5). SEM images of the dried and pulverized 
seawater-derived $\operatorname{Mg}(\mathrm{OH})_{2}$ reveal a rough surface morphology without a well-defined shape, in contrast to the standard brucite particles that contain visible prismatic crystallites (SI Figure S6). $\mathrm{X}$-ray diffraction (XRD) results (Figure $3 \mathrm{~b}$ ) show that both standard brucite and seawater-derived samples have prominent brucite peaks (PDF \# 44-1482), although the latter also contains a small peak around $2 \theta=29.5^{\circ}$ that can be assigned to calcite $\left(\mathrm{CaCO}_{3}\right.$, PDF \# 05-0586).(42) Derivative TGA weight loss curves for seawater-derived $\mathrm{Mg}(\mathrm{OH})_{2}$ after 2 rinse cycles (SI Figure S7) confirm the presence of calcite (10 mass \%) in addition to residual amounts of water (3.5 mass \%).

\subsection{Carbonation Curing of $\mathrm{Mg}(\mathrm{OH})_{2}$ Mixtures}

Before undergoing carbonation curing, distilled water, a co-reactant, was added to the dried $\mathrm{Mg}(\mathrm{OH})_{2}$ powders to maintain a water to solids mass ratio of 0.3 . Wet powders made from both standard brucite and seawater-derived $\mathrm{Mg}(\mathrm{OH})_{2}$ were then compacted into cylindrical samples and cured inside a sealed incubator where the samples were exposed to a humidified $\mathrm{CO}_{2}$ environment ( $20 \% \mathrm{CO}_{2}$ concentration by volume at $85 \% \mathrm{RH}$ ) at 1 bar total pressure for 48 hours. Detailed results of curing the standard brucite for varying amounts of time and varying water to solids ratios are reported in reference (43), but only the 48 -hour and 0.3 water to solids ratio results are included here. To compare the microstructure of the binders made from the two different source materials, the compacts were crushed back into a powder form and characterized by TGA, XRD, and SEM (Figure 4). Derivative weight loss TGA curves (Figures $4 \mathrm{a}$ and $4 \mathrm{~b}$ ) show that both types of samples still exhibit peaks at $\approx 400^{\circ} \mathrm{C}$ associated with residual (i.e. unreacted) brucite, but also reveal the emergence of new peaks at low temperature $\left(\approx 25^{\circ} \mathrm{C}-250^{\circ} \mathrm{C}\right)$ attributed to a combination of free or physically bound water and water removed from $\mathrm{Mg}$ carbonate hydrate phases such as hydromagnesite $\left(4 \mathrm{MgCO}_{3} \cdot \mathrm{Mg}(\mathrm{OH})_{2} \cdot 4 \mathrm{H}_{2} \mathrm{O}\right)$, dypingite $\left(4 \mathrm{MgCO}_{3} \cdot \mathrm{Mg}(\mathrm{OH})_{2} .5 \mathrm{H}_{2} \mathrm{O}\right)$, and nesquehonite $\left(\mathrm{MgCO}_{3} .3 \mathrm{H}_{2} \mathrm{O}\right)$. Additional mass change signal is also seen at higher temperatures $\left(\approx 400^{\circ} \mathrm{C}-500^{\circ} \mathrm{C}\right)$, which can be attributed to further mass loss from the $\mathrm{Mg}$ carbonate phases, (4446) although TGA is not able to distinguish between them. 
Standard Mg cement

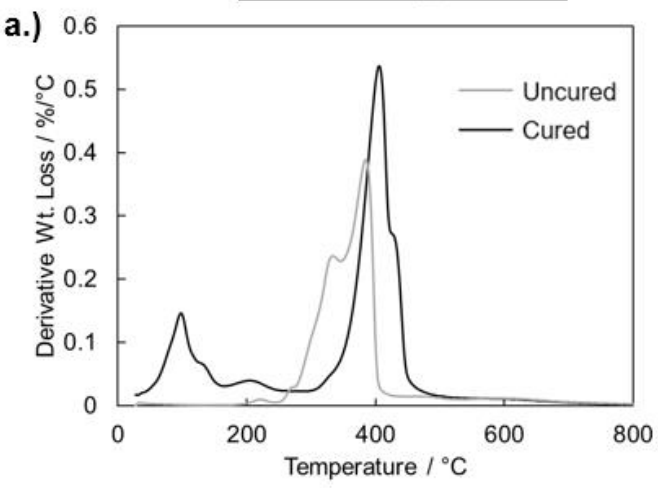

c.)

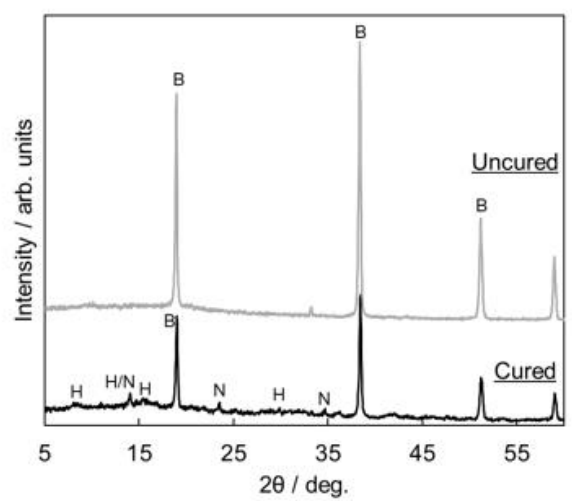

e.)
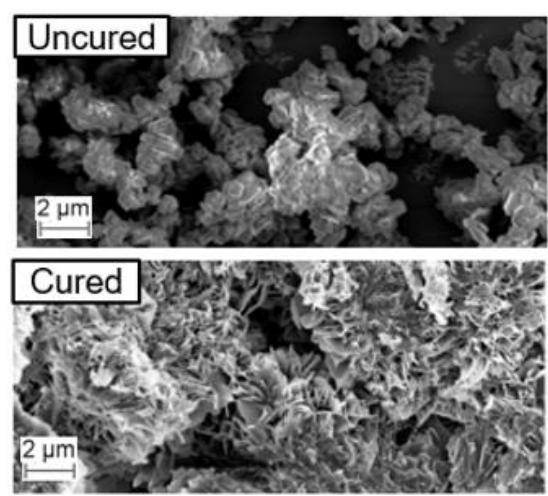

Seawater-derived cement

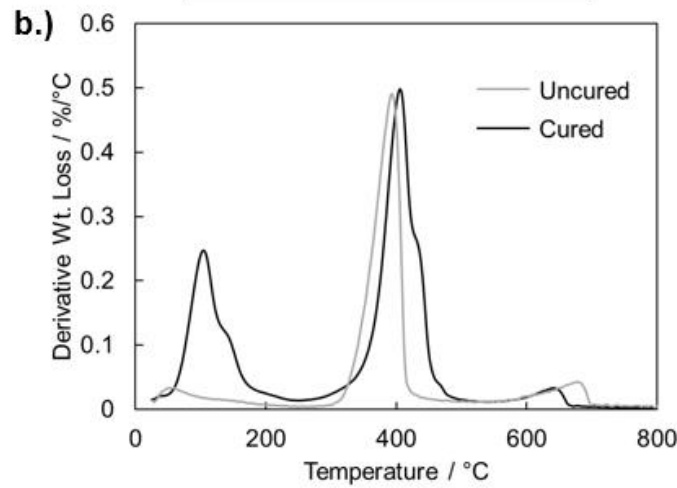

d.)

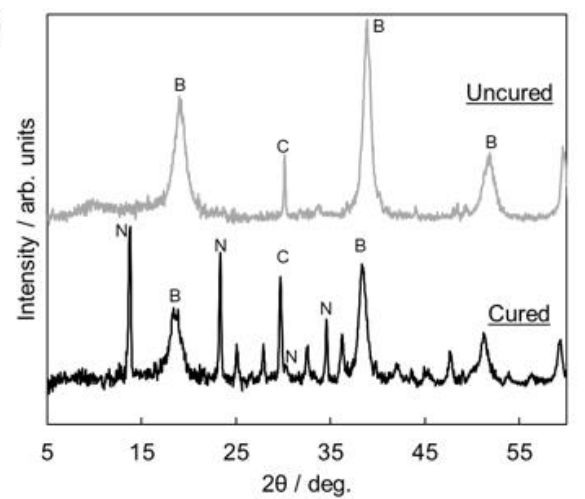

f.)
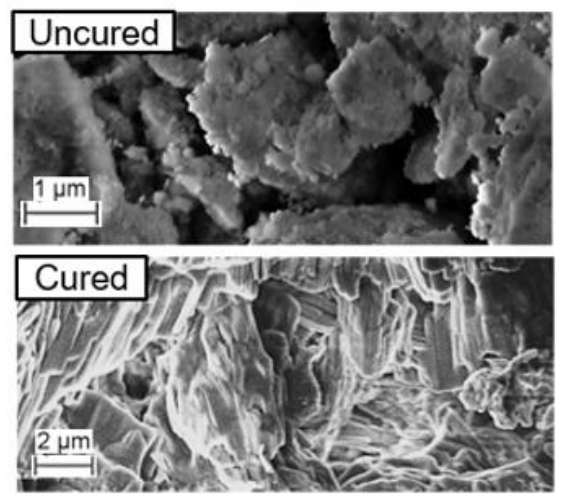

Figure 4. Microstructural characterization of standard (left column) and seawater-derived (right column) Mg cement samples before and after carbonation curing. Both samples were created using a water to solids mass ratio of 0.3 and were cured for 48 hours in humidified $\mathrm{CO}_{2}$ at $20 \%$ concentration and 1 bar total pressure. Samples were characterized before and after curing using a.),b.) TGA, c.),d.) XRD, and e.), f.) SEM. The following phases were identified in the diffractograms of c.) and d.): B - Brucite, $\mathrm{H}$ - Hydromagnesite, $\mathrm{N}$ - Nesquehonite, $\mathrm{C}$ - Calcite. Comparison data for the standard brucite samples are provided from reference (43).

The presence of carbonates in both types of cured specimens was also confirmed by XRD, as seen in the diffractograms for samples cured 48 hours in Figure 4c,d. For the cured standard brucite sample, significant decreases in the intensities of the brucite peaks are accompanied by the emergence of features that can be ascribed to the hydromagnesite and nesquehonite carbonate phases. Using the Rietveld refinement method (SI Section XIII), the mass percentages of hydromagnesite, brucite, and nesquehonite were estimated to be $52.2 \%, 40.0 \%$, and $7.8 \%$, 
respectively. The detailed compositions for all samples are provided in SI Table S1. In contrast to the XRD patterns for the cured standard brucite samples, those for the cured seawater-derived $\mathrm{Mg}(\mathrm{OH})_{2}$ samples (Figure 4d) show that nesquehonite is the predominant carbonate phase. The composition (mass \%) for the seawater-derived sample was calculated to be $49.3 \%$ nesquehonite, $42.9 \%$ residual brucite, $5.9 \%$ calcite, and $1.9 \%$ hydromagnesite (SI Table S1). Nesquehonite has also been observed in $\mathrm{CO}_{2}$-cured $\mathrm{Mg}(\mathrm{OH})_{2}$ compacts studied by De Silva et al..(31) Consistent with previous studies carrying out carbonation of $\mathrm{Mg}$ precursors at low pressure and temperature, $(19,31,47)$ none of the diffraction patterns in Figures $4 \mathrm{c}$ and $4 \mathrm{~d}$ contain peaks associated with magnesite, which is only known to form at higher temperature and pressure.(48, 49)

Clear evidence of carbonate formation was also observed in SEM images of both types of samples (Figures 4e and 4f). For the cured standard samples, rosette-like features are seen that are characteristic of hydromagnesite, as observed in other reactive $\mathrm{Mg}$-based systems.(50). If present throughout the microstructure, such features can serve to both densify and cement the material system and subsequently form a binder phase, similar to the effect of calcium-silicate-hydrate in Portland cement systems.(51) In contrast, SEM images of the cured seawater-derived sample reveal needle-like features that are characteristic of nesquehonite. $(28,50,52)$ Dypingite also exhibits rosette-like features $(17,53)$ and is characterized by a similar XRD pattern as hydromagnesite, but hydromagnesite proved a better fit for the data than dypingite based on quantitative analysis of XRD and TGA results. Nevertheless, given the similar chemical composition and morphology of hydromagnesite and dypingite, their impact on composite strength and durability is expected to be comparable. The moles of $\mathrm{CO}_{2}$ absorbed per mole of $\mathrm{Mg}$ precursor during formation of either carbonate are also the same, meaning that incorrect identification of hydromagnesite vs. dypingite does not affect interpretation of the carbon-uptake by the composite.

Several factors related to the $\mathrm{Mg}(\mathrm{OH})_{2}$ source material might explain the differences in composition of the cured standard and seawater-derived binders, including differences in $\mathrm{Mg}(\mathrm{OH})_{2}$ particle shape, particle and agglomerate size distributions, surface roughness, and trace impurities. Even with the same curing conditions and identical mix design, the attributes of the source material can lead to the formation of different polymorphs due to the influence of their starting structure and composition on local reaction conditions within the material during curing. For example, differences in the density and size of agglomerated particles in the source material can be expected to alter the local concentrations of $\mathrm{CO}_{2}$ and $\mathrm{H}_{2} \mathrm{O}$ within the agglomerates, with higher densities and larger agglomerate sizes resulting in lower concentrations of reactant species within the interior of the agglomerates.(54) Since reaction rate expressions for different reaction pathways can have different reaction orders with respect to reactants, $(48,49)$ it stands to reason that relative changes in local concentrations of $\mathrm{H}_{2} \mathrm{O}$ and $\mathrm{CO}_{2}$ within a specimen can lead to different products. However, other possible explanations, including interactions with impurity calcite crystallites and/or the formation of $\mathrm{CO}_{2}$-rich bubbles within nanoscopic voids within the particles,(54) cannot be ruled out at this time.

Additional standard Mg cement samples were prepared and cured to study change in the degree of carbonation for curing times between 3 hours and 120 hours. The carbonate composition was analyzed quantitatively using TGA and XRD, and is presented in Section XIII of the SI. The results show that the amount of carbonates continues to increase beyond 48 hours, while the 
amount of residual brucite decreases further. It can be reasonably expected that the seawaterderived cement will similarly show continued carbon-uptake with increased curing time since a similar amount of unreacted brucite remains available after 48 hours.

\subsection{Mechanical Performance of Mg-Binders}

To view the impact of carbonation on the strength of the resulting binders, compressive strength tests were carried out on standard brucite and seawater-derived cylinders subjected to carbonation curing for 48 hours. While the standard brucite samples resulted in a compressive strength of 33.4 $\pm 2.0 \mathrm{MPa}$, the compressive strength of seawater-derived $\mathrm{Mg}$ binder samples was found to be 22.5 $\pm 1.9 \mathrm{MPa}$, which is $\approx 33 \%$ lower than that of the standard samples.

Interestingly, both the standard brucite and seawater-derived samples had very similar initial densities $\left(1.49 \mathrm{~g} / \mathrm{cm}^{3}\right.$ and $1.44 \mathrm{~g} / \mathrm{cm}^{3}$, respectively) and final densities $\left(1.69 \mathrm{~g} / \mathrm{cm}^{3}\right.$ and 1.63 $\mathrm{g} / \mathrm{cm}^{3}$, respectively), suggesting that factors other than density may also be affecting compressive strength. For example, differences in particle size (SI Figure S5) and/ agglomerate size distributions may affect packing behavior during compaction and therefore alter the permeability of $\mathrm{H}_{2} \mathrm{O}$ and $\mathrm{CO}_{2}$ through the source material during carbonation. PSD and particle morphology may also affect the surface area available for products to form. It should also be recalled that the seawater-derived brucite contains $\approx 10 \% \mathrm{CaCO}_{3}$ by mass; this $\mathrm{CaCO}_{3}$ can be expected to be inert during $\mathrm{CO}_{2}$ curing such that it is effectively reducing the "active" $\mathrm{Mg}(\mathrm{OH})_{2}$ portion of the cement, which could lead to lower strength. Differences in the amounts of residual (unconverted) $\mathrm{Mg}(\mathrm{OH})_{2}$ could also affect strength, although the mass $\%$ residual $\mathrm{Mg}(\mathrm{OH})_{2}$ was within $3 \%$ for both types of samples (Table S1). Lastly, $\mathrm{CO}_{2}$ curing leads to the formation of carbonate phases with different morphologies in the two cured brucite systems, which may also impact strength of the binding matrix. Further investigations into all of these factors will be required to understand how the microstructure and composition of seawater- and standard brucite samples impact strength gain at multiple stages of the curing process.

Despite the differences in the 48-hour strength, seawater-derived cement can be expected to continue to gain strength with additional curing time, as we recently reported for standard brucite.(43) Moreover, conversion to nesquehonite is preferable from a carbon sequestration standpoint as the formation of this phase involves the absorption of more $\mathrm{CO}_{2}$ per unit weight of precursor cement than conversion to hydromagnesite. Equally important, the seawater-derived binder's strength of $22.5 \mathrm{MPa}$ is still comparable to the early compressive strength $(<7$ days after mixing) of ordinary Portland cement concrete and suitable to meet building codes. $(51,55)$

\subsection{Energy Use and Carbon Footprint}

Table 1 contains a comparison of the expected energy use and carbon footprint of the proposed seawater-derived $\mathrm{Mg}$ cement manufacturing process to conventional limestone-based Portland cement and magnesite-derived $\mathrm{Mg}$-cement processes. The functional unit is 1 ton of material (cement/concrete), and for $\mathrm{Mg}$ cement concretes, complete conversion of $\mathrm{Mg}$ precursors to carbonate (nesquehonite) is assumed as an upper limit on the amount of $\mathrm{CO}_{2}$ absorbed by these 
concretes. Methods and further assumptions underlying the calculations used to generate this table, along with the data sources, can be found in Section XIV of the SI.

Table 1 - Comparison of energy use and $\mathrm{CO}_{2}$ emissions of cement and concrete production between conventional Portland cement derived from limestone, $\mathrm{MgO}$ cement derived from magnesite, and the proposed $\mathrm{Mg}(\mathrm{OH})_{2}$ cement derived from seawater. The $\mathrm{CO}_{2}$ footprint for production of seawater-derived $\mathrm{Mg}$ cement assumes that all electricity used to power the $\mathrm{Mg}(\mathrm{OH})_{2}$ harvesting and processing is provided exclusively by a carbon-free electricity generator. If current U.S. grid electricity is used to power the process, the carbon footprint for seawater-derived $\mathrm{Mg}$ cement and concrete are 550 and $61 \mathrm{~kg} /$ ton, respectively. All other details of the calculations and key assumptions are included in Tables S3-S8 in the ESI.

\begin{tabular}{|c|c|c|c|c|}
\hline & \multicolumn{2}{|c|}{ Cement manufacturing } & \multicolumn{2}{c|}{ Concrete manufacturing } \\
\hline $\begin{array}{c}\text { Mineral } \\
\text { Feedstock }\end{array}$ & $\begin{array}{c}\text { Energy use } \\
\text { (kJ/ton of } \\
\text { cement) }\end{array}$ & $\begin{array}{c}\text { CO2 emissions } \\
\text { (kg/ton of } \\
\text { cement) }\end{array}$ & $\begin{array}{c}\text { Energy use } \\
\text { (kJ/ton of } \\
\text { concrete) }\end{array}$ & $\begin{array}{c}\mathbf{C O}_{2} \text { emissions } \\
\text { (kg/ton of } \\
\text { concrete) }\end{array}$ \\
\hline $\begin{array}{c}\text { Portland } \\
\text { cement from } \\
\text { limestone } \\
\left(\mathrm{CaCO}_{3}\right)\end{array}$ & $3.8 \times 10^{6}$ & 793 & $1.0 \times 10^{6}$ & 181 \\
\hline $\begin{array}{c}\mathrm{MgO} \text { from } \\
\text { magnesite }\end{array}$ & $5.9 \times 10^{6}$ & 1850 & $4.3 \times 10^{6}$ & 323 \\
\hline $\begin{array}{c}\mathrm{Mg}(\mathrm{OH})_{2} \text { from } \\
\text { seawater }\end{array}$ & $4.4 \times 10^{6}$ & $0^{*}$ & $2.8 \times 10^{6}$ & -93 \\
\hline
\end{tabular}

Focusing first on energy use, Table 1 shows that the Mg concretes consume more energy than Portland cement concrete. $\mathrm{MgO}$-derived concrete uses the most energy, which results from the energy-intensive mining and processing steps associated with the magnesite precursor, as well as the energy required to source $\mathrm{CO}_{2}$ for the carbonation process from direct air capture. Cement produced by the proposed seawater-derived $\mathrm{Mg}$ process has a lower energy demand and requires less $\mathrm{CO}_{2}$ per unit weight than $\mathrm{MgO}$-derived cement, but has a higher energy requirement than Portland cement.

Despite requiring more energy than Portland cement concrete, the proposed cement-from seawater process is still highly attractive because almost all of the energy inputs can be provided in the form of low- or zero-carbon electricity generated from renewable sources. Table 1 shows that the seawater-derived concrete can be carbon-negative, which is made possible because this process is powered by electricity, starts with carbon-free feedstock materials, and consumes $\mathrm{CO}_{2}$ during the carbon curing process (up to $755 \mathrm{~kg} \mathrm{CO}_{2}$ per ton of $\mathrm{Mg}(\mathrm{OH})_{2}$ for $100 \%$ conversion to nesquehonite). Meanwhile, conventional limestone- and magnesite-based cements have large carbon footprints due to direct and indirect $\mathrm{CO}_{2}$ emissions associated with calcination processes, which also lead to high carbon footprints for the resultant concretes. The carbon emissions of both conventional processes can be lowered if renewable energy is used for electricity-dependent processes, but electricity only typically comprises $5-10 \%$ of the total energy requirements. $(56,57)$ 
There has also been substantial interest in capturing $\mathrm{CO}_{2}$ released from magnesite or limestone during the calcination process, and reabsorbing that same $\mathrm{CO}_{2}$ for the formation of the $\mathrm{Mg}$ concrete or emerging carbonate-based Portland cement concretes.(13, 27, 58) However, these methods can never be carbon-negative because the maximum amount of $\mathrm{CO}_{2}$ that can be reabsorbed by the system is less than the amount released during production due to the carbonate feedstock.

\subsection{Conclusions and Future Prospects}

This study has demonstrated the viability of a process for producing Mg-based cement from seawater derived feedstock materials that has potential to turn one of the world's most carbonintensive industries into one of its biggest carbon sinks. However, significant advances must be made for this carbon-negative cement manufacturing scheme to become reality. First, it is essential that low-cost renewable electricity be used to power the process. As recently as 2019, only $19 \%$ of electricity in the US was derived from renewable or low carbon sources like nuclear.(59) Based on the current carbon intensity of the US grid electricity $\left(0.45 \mathrm{~kg} \mathrm{CO}_{2} \mathrm{kWh}^{-1}\right)$, the estimated carbon footprint of the proposed process would be $+61 \mathrm{~kg} \mathrm{CO}_{2}$ per ton of concrete, which represents a reduction of $67 \%$ compared to conventional Portland cement, but is not carbon-negative. Moving forward, carbon-negative cement involving electrochemical processing will only be possible if there is aggressive adoption of low carbon electricity generators. Secondly, it is important to note that $\mathrm{Mg}$-based cement is not suitable for use in steel reinforced concretes because its lower alkalinity compared to Portland cement provides less protection against corrosion of iron-based rebar.(60) This shortcoming motivates the development of alternative reinforcements to replace steel, but until that time, early applications of seawater-derived $\mathrm{Mg}$ cements will more likely be in unreinforced components such as masonry blocks. Finally, we note that a manufacturing plant based on our process should ideally be located on the coast in close proximity to the ocean. While this presents an opportunity for coastal communities, which comprise a significant fraction of the earth's population,(61) additional energy and carbon penalties would be incurred to transport precast seawater-derived concrete or vast volumes of seawater inland.

\section{Materials and Methods}

Chemicals- Except for natural seawater (Nutri-Seawater, Nature's Ocean), all solutions were prepared using 18.2 M $\Omega$-cm deionized water. Solutions were prepared using concentrated sulfuric acid (Certified ACS plus, Fisher Scientific), sodium chloride (ACS Reagent grade, Sigma Aldrich), sodium hydroxide (Certified ACS, Fisher Scientific), hydrochloric acid (Certified ACS plus, Fisher Scientific), potassium tetrachloroplatinate (99.99\% trace metal basis, Sigma Aldrich), and universal $\mathrm{pH}$ indicator dye ( $\mathrm{pH} 4-10$, Sigma Aldrich). Anhydrous $\mathrm{Mg}(\mathrm{OH})_{2}$ (Reagent grade, 95\%, Sigma Aldrich) was used as the source material for control samples. Mg-free natural seawater was prepared by first adding $4.86 \mathrm{~g}$ of $\mathrm{NaOH}$ per $\mathrm{L}$ of seawater to precipitate $\mathrm{Mg}^{2+}$ as $\mathrm{Mg}(\mathrm{OH})_{2}$. The solution was centrifuged at $5000 \mathrm{rpm}$ for 1 hour and decanted before lowering the $\mathrm{pH}$ back to $\mathrm{pH} \approx 7.50$ by titration with $1 \mathrm{M} \mathrm{HCl}$. The electrolytes were purged with either nitrogen gas $\left(\mathrm{N}_{2}\right.$, Purity Plus $99.999 \%$ purity) or hydrogen gas ( $\mathrm{H}_{2}$, Purity Plus $99.999 \%$ purity). 
Electrode fabrication- Electrode supports were made from carbon foam (McMaster-Carr, 100 pores per inches $(\mathrm{PPI})$, sheet resistance $\left.=7.87 \times 10^{-2} \mathrm{ohms} / \mathrm{sq}\right)$ with titanium foil used as an electrical connection and feedthrough. Each electrode was cut into a $15 \mathrm{~mm} \times 33 \mathrm{~mm}$ piece, with the thickness of the electrode inserted into the electrolysis cell cut to a thickness of $3.2 \mathrm{~mm}$ (SI Figure S8). Before electrodeposition, the carbon foam underwent a two-step chronoamperometry procedure for $10 \mathrm{~s}$ total in $0.5 \mathrm{M} \mathrm{H}_{2} \mathrm{SO}_{4}$ whereby the potential was alternated between $0.4 \mathrm{~V}$ vs. $\mathrm{Ag} \mid \mathrm{AgCl}$ and $-0.8 \mathrm{~V}$ vs. $\mathrm{Ag} \mid \mathrm{AgCl}$ with pulse widths of $5 \mathrm{~s}$. Electrodes were platinized by carrying out cyclic voltammetry $(\mathrm{CV})$ at $100 \mathrm{mV} \mathrm{s}^{-1}$ in a $3 \mathrm{mM} \mathrm{K}_{2} \mathrm{PtCl}_{4}+0.5 \mathrm{M} \mathrm{NaCl}$ electrolyte $(\mathrm{pH}=$ 2.60) for 21 cycles between $-0.7 \mathrm{~V}$ vs. $\mathrm{Ag} \mid \mathrm{AgCl}$ and $+0.3 \mathrm{~V}$ vs. $\mathrm{Ag} \mid \mathrm{AgCl}$.

Electrolyzer fabrication- Electrolyzers were 3D-printed using natural color acrylonitrile butadiene styrene (ABS) using a MakerGear M3-ID 3D printer (Makerbot Industries). The cell walls were printed with $100 \%$ solid infill. Design files are freely available at echem.io. Electrodes were inserted into slits in the cell body and sealed using epoxy (ClearWeld J.B Weld). Glass microscope slides serving as windows for in situ imaging were also attached with epoxy. High density poly ethylene connectors (1/8" ID, Cole-Parmer) were epoxied to the inlet and outlet ports.

Electrolysis experiments- All electrochemical experiments were carried out using a Biologic SP300 bi-potentiostat. A schematic of the set-up used for most electrolysis experiments is provided in SI Figure S9. Electrolyzer inlet and outlet ports were connected to feed reservoir and effluent collection beakers, respectively, using silicone tubing (Masterflex L/S, Cole Parmer). The effluent tubes were fed through peristaltic pumps (NE-9004, Syringe Pump), which were set to identical volumetric flow rates to ensure equal volumetric flow rates through the anode and cathode. The feed reservoir was constantly purged with $\mathrm{H}_{2}$ gas (99.999\% purity) at $1 \mathrm{~atm}$. The series resistance of the cell was measured by electrochemical impedance spectroscopy (EIS). Before electrolysis, electrodes were characterized by conducting CV cycling at $20 \mathrm{mV} \mathrm{s}^{-1}$ for 10 cycles in deaerated $0.5 \mathrm{M} \mathrm{H}_{2} \mathrm{SO}_{4}$ (SI Figure S10). Next, the cell was filled with synthetic or Mg-free natural seawater and electrodes were subjected to 5 more $\mathrm{CV}$ cycles while sweeping voltage between $-0.2 \mathrm{~V}$ and $1.1 \mathrm{~V}$ at $20 \mathrm{mV} \mathrm{s}^{-1}$. The $\mathrm{pH}$ of the anodic and cathodic effluent streams was measured under steady state operation while applying a cell voltage of $1.0 \mathrm{~V}$.

Precipitation experiments- $\mathrm{Mg}^{2+}$ was precipitated from natural seawater at room temperature by adding diluted $\mathrm{NaOH}$ at concentrations ranging from $0.03 \mathrm{M}$ to $0.5 \mathrm{M}$ to an Erlenmeyer flask containing $175-700 \mathrm{~mL}$ of seawater. After adding $\mathrm{NaOH}$, the solution was allowed to equilibrate for 5 minutes before being transferred into a $500 \mathrm{~mL}$ Nalgene bottle for centrifugation. Each sample underwent 2-3 rinsing steps and each centrifugation step was carried out at $5000 \mathrm{rpm}$ using an Avanti J-E Series JLA-10.500 Beckman Coulter Centrifuge. When the sample underwent two rinsing steps, the first centrifugation step lasted 2 minutes, the second step lasted 5 minutes, and the final step lasted 15 minutes. When the sample underwent three rinsing steps, the first centrifugation step lasted 2 minutes, the second and the third step lasted 5 minutes, and the final step lasted 15 minutes. After each centrifugation step, except for the final one, the supernatant was decanted and replaced by $400 \mathrm{~mL}$ of deionized water, and the bottle was shaken by hand for $\approx 2$ minutes. Following the final centrifugation step, $\mathrm{Mg}(\mathrm{OH})_{2(\mathrm{~s})}$ was collected from the bottle and spread onto a horizontally-suspended cloth and dried overnight in a fume hood using a fan.

Powder processing- Standard Sigma Aldrich $\mathrm{Mg}(\mathrm{OH})_{2}$ powder was used as obtained. Dry seawater-derived $\mathrm{Mg}(\mathrm{OH})_{2}$ (s) was ground using a ceramic mortar and pestle for one minute, then 
pulverized in a ball milling device (SPEX 8000 Mixer/Mill) for 5 minutes (SI Figure S11). Subsequent sieving, using $53 \mu \mathrm{m}$ and $75 \mu \mathrm{m}$ sieve sizes, resulted in $\mathrm{Mg}(\mathrm{OH})_{2}$ powder with a particle size distribution similar to that of the standard brucite (SI Figure S5). Particle size distributions were determined using a laser-based particle sizer (Beckman Coulter, Inc., LS 13320 MW).

Sample compaction and curing- Figure S12 in the SI shows the steps involved with compacting and curing the $\mathrm{Mg}(\mathrm{OH})_{2}$. Briefly, $40 \mathrm{~g}$ of dry $\mathrm{Mg}(\mathrm{OH})_{2}$ powder was combined with distilled water at a water to solids mass ratio of 0.3 . The wet powder was then divided into three identical cylindrical specimen molds, each with a diameter of 1 inch and a height of 1 inch. Each specimen was compacted in two layers, where each layer was subjected to a compaction pressure of $3 \mathrm{MPa}$ for two minutes using an MTS Criterion C43 Electromechanical Testing Machine. The water to solids ratio and the compaction pressure were selected based on a recent study by our groups that systematically explored the influence of processing conditions on the compressive strength of binders made by accelerated carbonation of lab grade brucite.(43) After compaction, specimens were demolded and weighed, and immediately placed in an incubator which maintained an environment of $20 \mathrm{vol} . \% \mathrm{CO}_{2}$, with a $25^{\circ} \mathrm{C} \pm 1^{\circ} \mathrm{C}$ operation temperature and $80 \% \pm 5 \%$ relative humidity. The compacts ( 3 repeat samples) were subjected to 48 hours of curing. After removal from the incubator, the cured specimens were weighed and their dimensions measured.

Compressive strength measurement- Specimens were capped with high strength gypsum paste, which was applied to each end of the specimen and solidified against a smooth surface. This capping ensured that each specimen had orthogonal and smooth bearing surfaces, in order to minimize stress concentrations and maintain loading uniformity during the compression test. The compression tests were conducted using a hydraulic testing machine (Instron 5984 Universal Testing Machine) at a displacement rate of $0.15 \mathrm{~mm} / \mathrm{min}$.

Characterization- Characterization was performed on both raw and cured samples to help identify effects of carbonation. The raw powder was used as is for characterization. For the cured samples, one specimen from each batch was picked and pulverized into a fine powder. It was then characterized by TGA, XRD, and SEM. About $15 \mathrm{mg}$ of powder was used for the TGA scans in a TA Instrument Q50 thermogravimetric analyzer. The samples were heated from room temperature to $1000^{\circ} \mathrm{C}$ at a rate of $20^{\circ} \mathrm{C} \mathrm{min}^{-1}$ in an inert $\mathrm{N}_{2}$ atmosphere. XRD characterization was performed using a Malvern Panalytical XPert ${ }^{3}$ powder diffractometer. Powdered samples were packed into a circular sample holder and exposed to $\mathrm{Cu} \mathrm{K \alpha}$ radiation (operating conditions: $40 \mathrm{~V}$ and $40 \mathrm{~mA}$ ). XRD scans were carried out for $2 \theta$ angles between $5^{\circ}$ to $80^{\circ}$ at a step size of $0.04^{\circ}$ and step interval of 0.05 seconds per step. MDI's JADE 6 software was used for phase identification and Maud software was used to apply Rietveld refinement method. Further details of phase composition calculations, based on both XRD and TGA results, are provided in SI section III. SEM images were obtained using a Zeiss Sigma VP Scanning Electron Microscope. Powder was scattered on carbon tape and coated with $\mathrm{Au} \mathrm{Pd}$ to reduce charging.

\section{Acknowledgments}

SK and DE acknowledge seed funding from the Columbia University School of Applied Sciences and Engineering Interdisciplinary Research Seed (SIRS) program. The authors also acknowledge 
Scott Banta for use of his lab's centrifuge, Alissa Park for helpful discussions and the use of equipment in her laboratory, and Athanasios Bourtsalas for helpful discussions.

\section{Notes:}

The authors declare the following competing financial interest(s): DE is a co-founder of sHYp, BV PBC.

\section{References}

1. Mineral commodity summaries 2020. in Mineral Commodity Summaries (Reston, VA), p 204 (2020).

2. International Energy Agency (IEA) (2018) Technology Roadmap - Low-Carbon Transition in the Cement Industry.

3. R. M. Andrew, Global CO2 emissions from cement production, 1928-2018. Earth System Science Data 11, 1675-1710 (2019).

4. International Panel on Climate Change (IPCC), 2018: Summary for Policymakers. In: Global Warming of $1.5^{\circ} \mathrm{C}$. An IPCC Special Report on the impacts of global warming of $1.5^{\circ} \mathrm{C}$ above pre-industrial levels and related global greenhouse gas emission pathways, in the context of strengthening the global response to the threat of climate change, sustainable development, and efforts to eradicate poverty. eds V. Masson-Delmotte et al.

5. K. L. Scrivener, V. M. John, E. M. Gartner, Eco-efficient cements: Potential economically viable solutions for a low-CO2 cement-based materials industry. Cem. Concr. Res. 114, 2-26 (2018).

6. Alkali Activated Materials: State-of-the-Art Report, RILEM TC 224-AAM (Springer Netherlands, ed. 1, 2014), pp. XIV, 388.

7. J. L. Provis, Alkali-activated materials. Cem. Concr. Res. 114, 40-48 (2018).

8. Y. Dhandapani, T. Sakthivel, M. Santhanam, R. Gettu, R. G. Pillai, Mechanical properties and durability performance of concretes with Limestone Calcined Clay Cement (LC3). Cem. Concr. Res. 107, 136-151 (2018).

9. H. Justnes, T. A. Østnor (2015) Alternative Binders Based on Lime and Calcined Clay. (Springer Netherlands, Dordrecht), pp 51-57.

10. M. C. G. Juenger, F. Winnefeld, J. L. Provis, J. H. Ideker, Advances in alternative cementitious binders. Cem. Concr. Res. 41, 1232-1243 (2011).

11. C. J. Shi, A. F. Jimenez, A. Palomo, New cements for the 21st century: The pursuit of an alternative to Portland cement. Cem. Concr. Res. 41, 750-763 (2011).

12. K. Vance et al., Direct Carbonation of $\mathrm{Ca}(\mathrm{OH}) 2$ Using Liquid and Supercritical CO2: Implications for Carbon-Neutral Cementation. Industrial \& Engineering Chemistry Research 54, 8908-8918 (2015).

13. Q. H. Li et al., A Novel Strategy for Carbon Capture and Sequestration by rHLPD Processing. Frontiers in Energy Research 4 (2016).

14. Z. Li, Z. He, X. Chen, The Performance of Carbonation-Cured Concrete. Materials (Basel) 12 (2019). 
15. J. Kline, C. Kline (2020) CO2 Capture From Cement Manufacture and Reuse in Concrete. in IEEE Industry Applications Magazine (IEEE), pp 42-49.

16. A. Al-Tabbaa, "Reactive magnesia cement" in Eco-Efficient Concrete, F. PachecoTorgal, S. Jalali, J. Labrincha, V. M. John, Eds. (2013), 10.1533/9780857098993.4.523, pp. 523543.

17. C. Unluer, "Carbon dioxide sequestration in magnesium-based binders" in Carbon Dioxide Sequestration in Cementitious Construction Materials, F. Pacheco-Torgal, C. Shi, A. P. Sanchez, Eds. (Woodhead Publishing, 2018), https://doi.org/10.1016/B978-008-102444-7.00007-1 chap. 7, pp. 129-173.

18. N. T. Dung, C. Unluer, Sequestration of $\mathrm{CO} 2$ in reactive $\mathrm{MgO}$ cement-based mixes with enhanced hydration mechanisms. Construction and Building Materials 143, 71-82 (2017).

19. N. T. Dung, C. Unluer, Development of $\mathrm{MgO}$ concrete with enhanced hydration and carbonation mechanisms. Cem. Concr. Res. 103, 160-169 (2018).

20. W. G. Shen et al., Is magnesia cement low carbon? Life cycle carbon footprint comparing with Portland cement. Journal of Cleaner Production 131, 20-27 (2016).

21. S. A. Walling, J. L. Provis, Magnesia-Based Cements: A Journey of 150 Years, and Cements for the Future? Chem. Rev. 116, 4170-4204 (2016).

22. M. Seeger, W. Otto, W. Flick, F. Bickelhaupt, O. S. Akkerman, "Magnesium Compounds" in Ullmann's Encyclopedia of Industrial Chemistry. (2011), 10.1002/14356007.a15_595.pub2.

23. K. Z. House, C. H. House, D. P. Schrag, M. J. Aziz, Electrochemical acceleration of chemical weathering as an energetically feasible approach to mitigating anthropogenic climate change. Environ. Sci. Technol. 41, 8464-8470 (2007).

24. G. H. Rau, J. R. Baird, Negative-CO2-emissions ocean thermal energy conversion. Renewable \& Sustainable Energy Reviews 95, 265-272 (2018).

25. G. H. Rau, H. D. Willauer, Z. J. Ren, The global potential for converting renewable electricity to negative-CO2-emissions hydrogen. Nature Climate Change 8, 621-+ (2018).

26. R. J. Gilliam et al., Low Voltage Electrochemical Process for Direct Carbon Dioxide Sequestration. J. Electrochem. Soc. 159, B627-B628 (2012).

27. L. D. Ellis, A. F. Badel, M. L. Chiang, R. J. Y. Park, Y. M. Chiang, Toward electrochemical synthesis of cement-An electrolyzer-based process for decarbonating $\mathrm{CaCO} 3$ while producing useful gas streams. Proc. Natl. Acad. Sci. U.S.A. 117, 1258412591 (2020).

28. S. Ma, A. H. Akca, D. Esposito, S. Kawashima, Influence of aqueous carbonate species on hydration and carbonation of reactive $\mathrm{MgO}$ cement. Journal of CO2 Utilization 41, 101260 (2020).

29. S. Ruan, E.-H. Yang, C. Unluer, Production of reactive magnesia from desalination reject brine and its use as a binder. Journal of CO2 Utilization https://doi.org/10.1016/j.jcou.2020.101383, 101383 (2020).

30. H. Dong, E.-H. Yang, C. Unluer, F. Jin, A. Al-Tabbaa, Investigation of the properties of $\mathrm{MgO}$ recovered from reject brine obtained from desalination plants. Journal of Cleaner Production 196, 100-108 (2018). 
31. P. De Silva, L. Bucea, V. Sirivivatnanon, Chemical, microstructural and strength development of calcium and magnesium carbonate binders. Cem. Concr. Res. 39, 460465 (2009).

32. O. O. Talabi, A. E. Dorfi, G. D. O'Neil, D. V. Esposito, Membraneless electrolyzers for the simultaneous production of acid and base. Chem. Commun. 53, 8006-8009 (2017).

33. B. D. Patterson et al., Renewable $\mathrm{CO} 2$ recycling and synthetic fuel production in a marine environment. Proc. Natl. Acad. Sci. U.S.A. 116, 12212-12219 (2019).

34. I. A. Digdaya et al., A direct coupled electrochemical system for capture and conversion of CO2 from oceanwater. Nature Communications 11, 4412 (2020).

35. M. D. Eisaman et al., CO2 extraction from seawater using bipolar membrane electrodialysis. Energy Environ. Sci. 5, 7346-7352 (2012).

36. F. Sabatino et al., Evaluation of a Direct Air Capture Process Combining Wet Scrubbing and Bipolar Membrane Electrodialysis. Industrial \& Engineering Chemistry Research 59, 7007-7020 (2020).

37. S. Dresp, F. Dionigi, M. Klingenhof, P. Strasser, Direct Electrolytic Splitting of Seawater: Opportunities and Challenges. Acs Energy Letters 4, 933-942 (2019).

38. X. Y. Lu et al., A sea-change: manganese doped nickel/nickel oxide electrocatalysts for hydrogen generation from seawater. Energy Environ. Sci. 11, 1898-1910 (2018).

39. W. M. Tong et al., Electrolysis of low-grade and saline surface water. Nature Energy 5, 367-377 (2020).

40. $\quad$ "SOLUBILITY PRODUCT CONSTANTS OF INORGANIC SALTS" in CRC Handbook of Chemistry and Physics, J. R. Rumble, Ed. (CRC Press/Taylor \& Francis, Boca Raton, FL), vol. 101st Edition (Internet Version 2020).

41. M. P. Hain, D. M. Sigman, J. A. Higgins, G. H. Haug, The effects of secular calcium and magnesium concentration changes on the thermodynamics of seawater acid/base chemistry: Implications for Eocene and Cretaceous ocean carbon chemistry and buffering. Global Biogeochem. Cycles 29, 517-533 (2015).

42. J. Dweck, P. M. Buchler, A. C. V. Coelho, F. K. Cartledge, Hydration of a Portland cement blended with calcium carbonate. Thermochim. Acta 346, 105-113 (2000).

43. A. H. Akca, S. Ma, D. V. Esposito, S. Kawashima, Evaluation of the Mechanical Performance of Compacted Magnesium Hydroxide After Carbonation Curing. J. Mater. Civ. Eng. ((Under revision)).

44. R. L. Frost, S. Bahfenne, J. Graham, W. N. Martens, Thermal stability of artinite, dypingite and brugnatellite-Implications for the geosequestration of green house gases. Thermochim. Acta 475, 39-43 (2008).

45. G. Jauffret, J. Morrison, F. P. Glasser, On the thermal decomposition of nesquehonite. $J$. Therm. Anal. Calorim. 122, 601-609 (2015).

46. V. Vágvölgyi et al., Controlled rate thermal analysis of hydromagnesite. J. Therm. Anal. Calorim. 92, 893-897 (2008).

47. A. Botha, C. A. Strydom, Preparation of a magnesium hydroxy carbonate from magnesium hydroxide. Hydrometallurgy 62, 175-183 (2001).

48. J. Highfield, J. Chen, M. Haghighatlari, J. Åbacka, R. Zevenhoven, Low-temperature gas-solid carbonation of magnesia and magnesium hydroxide promoted by nonimmersive contact with water. RSC Advances 6, 89655-89664 (2016).

49. W. B. White, Thermodynamic equilibrium, kinetics, activation barriers, and reaction mechanisms for chemical reactions in Karst Terrains. Environ. Geol. 30, 46-58 (1997). 
50. N. T. Dung, A. Lesimple, R. Hay, K. Celik, C. Unluer, Formation of carbonate phases and their effect on the performance of reactive $\mathrm{MgO}$ cement formulations. Cem. Concr. Res. 125, 105894 (2019).

51. S. Mindess, J. F. Young, D. Darwin, Concrete (Prentice Hall, Upper Saddle River (New Jersey), 2003).

52. V. Ferrini, C. De Vito, S. Mignardi, Synthesis of nesquehonite by reaction of gaseous $\mathrm{CO} 2$ with $\mathrm{Mg}$ chloride solution: Its potential role in the sequestration of carbon dioxide. J. Hazard. Mater. 168, 832-837 (2009).

53. I. M. Power, S. A. Wilson, J. M. Thom, G. M. Dipple, G. Southam, Biologically induced mineralization of dypingite by cyanobacteria from an alkaline wetland near Atlin, British Columbia, Canada. Geochem. Trans. 8, 13 (2007).

54. S. F. Jones, G. M. Evans, K. P. Galvin, Bubble nucleation from gas cavities - a review. Adv. Colloid Interface Sci. 80, 27-50 (1999).

55. A. Committee, I. O. f. Standardization (2008) Building code requirements for structural concrete (ACI 318-08) and commentary. (American Concrete Institute).

56. E. Worrell, K. Kermeli, C. Galitsky, Energy efficiency improvement and cost saving opportunities for cement making an ENERGY STAR® guide for energy and plant managers (EPA-United States Environmental Protection Agency, 2013).

57. F. Schorcht, I. Kourti, B. Scalet, S. Roudier, L. Delgado Sancho (2013) Best Available Techniques (BAT) Reference Document for the Production of Cement, Lime and Magnesium Oxide: Industrial Emissions Directive 2010/75/EU. in JRC Reference Reports (Publications Office of the European Union, Luxembourg), p 475.

58. M. M. Bomgardner (2014) Curing Cement's CO2 Weakness. in Chemical \& Engineering News (American Chemical Society), pp 15-16.

59. Anonymous, Monthly Energy Review, April 2020. (U.S. Energy Information Administration).

60. S. Ahmad, Reinforcement corrosion in concrete structures, its monitoring and service life prediction-a review. Cem. Concr. Compos. 25, 459-471 (2003).

61. UN (2017) Factsheet: People and Oceans. in The Ocean Conference (New York, NY). 